\title{
PENGARUH MERGER TERHADAP RETURN SAHAM PERUSAHAAN PENGAKUISISI YANG TERDAFTAR DI BURSA EFEK JAKARTA DENGAN KINERJA KEUANGAN SEBAGAI VARIABEL INTERVENING
}

\author{
Ramadona Simbolon \\ Dosen Fakultas Ekonomi UISU
}

\begin{abstract}
ABSTRAK
Penelitian ini bertujuan untuk menguji secara empiris pengaruh merger terhadap return saham dan menguji pengaruh merger terhadap return saham perusahaan pengakuisisi dengan kinerja keuangan sebagai variabel intervening. Pengujian hipotesis diuji dengan menggunakan derajat signifikan 5\%. Populasi terdiri dari 334 perusahaan yang terdaftar di Bursa Efek Indonesia. Metode pengambilan sampel menggunakan purpossive sampling. Jumlah sampel dalam penelitian ini adalah sebanyak 34 perusahaan dengan periode pengamatan 6 (enam) tahun yaitu periode 2000-2006. Pengujian hipotesis dilakukan dengan menggunakan analisis jalur dan uji t.

Hasil penelitian menunjukkan bahwa merger berpengaruh terhadap return saham perusahaan pengakuisisi yang berarti merger berpengaruh langsung terhadap return saham perusahaan pengakuisisi. Dengan demikian hipotesis yang menyatakan bahwa merger berpengaruh terhadap return saham didukung secara empiris atau diterima. Hasil penelitian juga menunjukkan bahwa merger tidak berpengaruh terhadap return saham dengan kinerja keuangan sebagai variabel intervening. Dengan demikian hipotesis yang menyatakan bahwa merger berpengaruh terhadap return saham perusahaan pengakuisisi melalui kinerja keuangan sebagai variabel intervening tidak didukung secara empiris atau ditolak.
\end{abstract}

\section{Kata kunci : $\quad$ Merger, Return Saham, Kinerja Keuangan}




\title{
RAMADONA
}

\begin{abstract}
This study aims to examine empirically the effect of mergers on stock return and tested the effect of mergers on acquirer's stock return with the financial performance as an intervening variable. Testing of hypotheses are tested using 5\% significant level. The population consists of 334 companies listed on the Indonesian Stock Exchange. Purposive sampling method using 34 samples obtained by sampling a company that merged with the observation period of 6 (six) years, from 2000 to 2006 period. Testing was conducted by path analysis.

The results of examination showed that the merger affect the acquirer's stock return, which means the merger directly influence the acquirer's stock return. Thus the hypothesis which states that the merger effect on stock returns are empirically supported or accepted. The results also indicated that the merger did not affect the financial performance of the stock return as an intervening variable. Thus the hypothesis that mergers affect the acquirer's stock returns through its financial performance as an intervening variable is not supported by empirical or rejected.
\end{abstract}

Key words: Merger, Stock Return, Financial Performance 


\section{PENDAHULUAN}

\section{A. Latar Belakang Penelitian}

Tujuan investor menanamkan dananya pada sekuritas saham adalah memperoleh tingkat pengambalian (return) tertentu dengan resiko minimal. Tingkat pengembalian (return) atas kepemilikan saham dapat diperoleh dalam dua bentuk, yaitu dividen dan capital gain (harga jual saham lebih tinggi dari harga belinya). Saat melakukan investasi saham, investor akan memilih saham perusahaan mana yang akan memberikan return yang tinggi. Harga pasar saham memberikan ukuran yang objektif mengenai nilai investasi pada sebuah perusahaan (Resmi, 2002). Oleh karena itu harga saham merupakan harapan investor. Investor harus dapat menganalisa apakah harga saham yang terjadi cukup layak untuk dibeli dan harus pula mendeteksi pergerakan harganya, mengetahui variabel apa saja yang menjadi penentu terhadap harga saham tersebut, apakah bersifat fundamental, teknikal, maupun sosial politik. Setiap variabel mempunyai efek yang relatif berbeda, sehingga adanya harga saham yang bersifat overvalued ataupun undervalued pada hakekatnya disebabkan adanya kekuatan variabel penentu yang berbeda.

Salah satu fakta yang mempengaruhi return saham adalah kebijakan merger, karena merger dianggap jalan cepat untuk mewujudkan tujuan perusahaan dimana perusahaan tidak perlu memulai dari awal suatu bisnis baru. Merger juga dianggap dapat menciptakan sinergi, yaitu nilai keseluruhan perusahaaan setelah merger yang lebih besar daripada penjumlahan nilai masing-masing perusahaan sebelum merger. Selain itu merger dapat memberikan banyak keuntungan bagi perusahaan antara lain peningkatan kemampuan dalam pemasaran, riset, skill manajerial, transfer teknologi, dan efisiensi berupa penurunan biaya produksi.

Di Amerika Serikat, aktivitas merger merupakan hal yang biasa terjadi. Bahkan di era 1980an telah terjadi kira-kira 55.000 aktivitas merger sehingga tahun 1980an sering disebut sebagai dekade merger (Hitt, 2002). Sementara di Indonesia aktivitas merger mulai marak dilakukan seiring dengan majunya pasar modal di Indonesia. Beberapa contoh perusahaan di Bursa Efek Jakarta (BEJ) yang melakukan merger diantaranya adalah PT Semen Gresik yang mengakuisisi PT Semen Padang, PT Gudang Garam merger dengan PT Surya Pamenang dan PT Nutricia yang mengakuisisi PT Sari Husada.

Untuk menilai bagaimana keberhasilan merger yang dilakukan, dapat dilihat pengaruhnya secara langsung terhadap return saham perusahaan yang melakukan merger dan secara tidak langsung melalui kinerja keuangan. Beberapa penelitian yang menjadi acuan diantaranya adalah Payamta dan Setiawan (2004) yang meneliti kinerja keuangan perusahaan yang melakukan merger dari rasio-rasio keuangan dan return saham di sekitar peristiwa terjadinya merger. Hasil penelitiannya menunjukkan rasio-rasio keuangan dua tahun sebelum dan sesudah peristiwa merger tidak mengalami perubahan yang signifikan. Sedangkan return saham sebelum merger positif, namun setelah merger justru negatif. Penelitian ini sejalan dengan penelitian yang dilakukan Widjanarko (2006) yang menunjukkan tidak ada perubahan yang signifikan dari kinerja keuangan perusahaan yang diproksikan dari rasio-rasio keuangan dua tahun sebelum dan sesudah merger. 
Penelitian yang membandingkan antara akuisitor dan non akuisitor dilakukan Wibowo dan Pakereng (2001) yang meneliti return saham perusahaan akuisitor dan non akuisitor. Hasilnya menunjukkan bahwa baik akuisitor dan non akuisitor samasama memperoleh return yang negatif di seputar pengumuman merger. Penelitian lainnya dilakukan Sutrisno dan Sumarsih (2004) yang meneliti return saham perusahaan yang melakukan merger dalam jangka panjang yaitu dengan jangka waktu pengamatan satu tahun sebelum dan dua tahun sesudah merger, menunjukkan hasilnya bahwa merger memberi pengaruh pada return saham yang bisa bernilai positif dan negatif walaupun tidak signifikan secara statistik.

Selanjutnya penelitian yang menyangkut kinerja keuangan serta pengaruhnya terhadap return saham antara lain dilakukan Raharjo (2005) yang meneliti pengaruh kinerja keuangan terhadap return saham pada perusahaan LQ-45 di Bursa Efek Jakarta. hasil penelitiannya menunjukkan bahwa return on asset (ROA) mempunyai pengaruh terhadap return saham. Asna dan Nu Graha (2006) menguji pengaruh rasio keuangan terhadap return saham perbankan yang terdaftar di Bursa Efek Jakarta dengan hasil penelitian rasio loan to deposit ratio (LDR) dan beban operasional terhadap pendapatan operasional (BOPO) berpengaruh signifikan terhadap return saham perbankan yang terdaftar di BEJ, sedangkan capital adequacy ratio (CAR) dan ROA tidak berpengaruh signifikan terhadap return saham serta LDR memiliki pengaruh yang dominan terhadap return saham. Ulupui (2007) menguji pengaruh rasio likuiditas, leverage, aktivitas, dan profitabilitas terhadap return saham (studi pada perusahaan makanan dan minuman dengan kategori industri barang konsumsi di BEJ) dengan hasil penelitian bahwa current ratio memiliki pengaruh yang positif dan signifikan terhadap return saham satu periode ke depan, variabel return on asset berpengaruh positif dan signifikan terhadap return saham satu periode ke depan, variabel debt to equity rasio menunjukkan hasil yang positif, tetapi tidak signifikan, variabel total asset turn over menunjukkan hasil yang negatif dan tidak signifikan.

Berdasarkan hasil-hasil penelitian terdahulu terlihat adanya fenomena berupa ketidakkonsistenan antara hasil-hasil penelitian dengan teori yang ada, terutama pengaruh langsung variabel merger terhadap return saham perusahaan pengakuisisi. Teori menyatakan bahwa merger dapat menciptakan sinergi, yaitu nilai keseluruhan perusahaaan setelah merger yang lebih besar daripada penjumlahan nilai masingmasing perusahaan sebelum merger. Selain itu merger dapat memberikan banyak keuntungan bagi perusahaan antara lain peningkatan kemampuan dalam pemasaran, riset, skill manajerial, transfer teknologi, dan efisiensi berupa penurunan biaya produksi yang tentunya akan meningkatkan return saham perusahaan-perusahaan yang melakukan merger. Sedangkan penelitian-penelitian sebelumnya menunjukkan bahwa baik akuisitor dan non akuisitor sama-sama memperoleh return yang negatif setelah dilaksanakannya merger.

Fenomena praktis yang terjadi terkait dengan penelitian ini adalah akan dikeluarkannya undang-undang pemberian insentif terhadap perusahaan-perusahaan yang melakukan merger khususnya industri perbankan sebagai salah satu upaya memperkuat struktur dan permodalan perusahaan khususnya bank. Sementara para pihak lain masih banyak yang menguji kelayakan pemberian insentif tersebut, karena pada dasarnya merger bertujuan untuk mengembangkan usaha. 
Banyak pemilik perusaaan khususnya bank merasa masih saja bimbang memutuskan opsi mana yang akan menjadi pilihan, apakah merger, menjual saham atau membikin induk usaha (holding company). Ketiga pilihan itu memang samasama bukan hal yang mudah dilakukan. Bila keputusan yang mereka ambil adalah merger, maka mereka harus mampu untuk mengurangi dampak pemutusan hubungan pekerja (PHK) dengan para karyawannya. Permasalahan yang muncul bila perusahaan mem-PHK karyawan akibat merger. Aksi penolakan karyawan mungkin sekali terjadi. Bahkan kalaupun pemegang saham memberikan pesangon yang lumayan, para karyawan belum tentu bisa langsung menerima. Permasalahan lain yang mungkin akan timbul akibat merger adalah masalah perpajakan.

Fenomena lain adalah bahwa minimnya pelaku pasar modal sangat mempengaruhi operasional perusahaan, terutama perusahaan-perusahaan yang membutuhkan tambahan dana. Diharapkan dengan adanya informasi merger akan meningkatkan kinerja keuangan dan mempengaruhi perilaku para investor untuk berinvestasi dengan cara memilih jenis saham yang layak untuk dijadikan lahan investasi. Perubahan perilaku investor tersebut tentunya akan menghindarkan para investor lain dari capital loss dan kebangkrutan perusahaan sebagaimana yang terjadi pada saat krisis global tahun 2008.

Dengan ketidakkonsistenan antara hasil-hasil penelitian terdahulu dengan teori yang ada dan fenomena-fenomena di atas, maka peneliti tertarik untuk meneliti pengaruh merger terhadap return saham perusahaan pengakuisisi yang terdaftar di Bursa Efek Indonesia baik secara langsung maupun tidak langsung melalui kinerja keuangan.

\section{B. Rumusan Masalah}

Berdasarkan latar belakang penelitian, dirumuskan masalah sebagai berikut :

a. Apakah merger berpengaruh terhadap return saham perusahaan pengakuisisi.

b. Apakah merger berpengaruh terhadap return saham perusahaan pengakuisisi melalui kinerja keuangan.

\section{Tujuan Penelitian}

Tujuan dari penelitian ini adalah :

a. Menguji pengaruh merger terhadap return saham perusahaan pengakuisisi.

b. Menguji pengaruh merger terhadap return saham perusahaan pengakuisisi melalui kinerja keuangan.

\section{E. Manfaat Penelitian}

Manfaat penelitian ini adalah :

a. Menambah pengetahuan dan wawasan peneliti, khususnya tentang merger, return saham dan kinerja keuangan.

b. Sebagai bahan informasi bagi manajer dan investor dalam pengambilan keputusan, khususnya terkait dengan merger, return saham dan kinerja keuangan.

c. Hasil penelitian ini dapat digunakan sebagai bahan acuan untuk peneliti dan calon peneliti sesuai dengan topik penelitian ini dengan variabel yang berbeda. 


\section{F. Originalitas}

Disadari bahwa penelitian mengenai pengaruh merger terhadap return saham perusahaan dengan kinerja keuangan sebagai variabel intervening belum pernah dilakukan, sehingga peneliti menjadi tertarik untuk menelitinya. Adapun ide yang dijadikan dasar dilakukannya penelitian ini adalah Wibowo dan Pakereng (2001).

Berdasarkan penelitian-penelitian sebelumnya, maka yang menjadi perbedaan dengan penelitian ini adalah :

1. Penelitian-penelitian sebelumnya tidak memiliki variabel intervening, sedangkan penelitian ini menggunakan variabel intervening yaitu kinerja keuangan.

2. Analisis data penelitian-penelitian sebelumnya hanya menggunakan uji beda sedangkan penelitian ini menggunakan analisis regresi dan analisis jalur (path analysis)

\section{TINJAUAN PUSTAKA}

\section{A. Return Saham}

Corrado dan Jordan (2000:5) menyatakan bahwa "return from investment security is cash flow and capital gain/loss". Berdasarkan pendapat yang telah dikemukakan, dapat diambil kesimpulan return saham adalah keuntungan yang diperoleh dari kepemilikan saham investor atas investasi yang dilakukannya, yang terdiri dari dividen dan capital gain/loss.

Return saham dapat dibedakan menjadi dua yaitu return sesungguhnya (realized return) dan return yang diharapkan atau return ekspektasi. return sesungguhnya merupakan return yang sudah terjadi yang dihitung dari selisih harga sekarang relatif terhadap harga sebelumnya. Sedang return ekspektasi adalah return yang diharapkan akan diperoleh oleh investor di masa yang akan datang.

Return tersebut memiliki dua komponen yaitu current income dan capital gain (Wahyudi, 2003). Bentuk dari current income berupa keuntungan yang diperoleh melalui pembayaran yang bersifat periodik berupa dividen sebagai hasil kinerja fundamental perusahaan. Sedangkan capital gain berupa keuntungan yang diterima karena selisih antara harga jual dan harga beli saham. Besarnya capital gain suatu saham akan positif, bilamana harga jual dari saham yang dimiliki lebih tinggi dari harga belinya.

Menurut Jogiyanto (2003:109) saham dibedakan menjadi dua: (1) return realisasi merupakan return yang telah terjadi, (2) return ekspektasi merupakan return yang diharapkan akan diperoleh oleh investor di masa yang akan datang. Berdasarkan pengertian return, bahwa return suatu saham adalah hasil yang diperoleh dari investasi dengan cara menghitung selisih harga saham periode berjalan dengan periode sebelumnya dengan mengabaikan dividen, maka dapat ditulis rumus (Ross et al., 2003:238) 


$$
R_{t}=\frac{P_{t}-P_{t-1}}{P_{t-1}}
$$

Keterangan :

$\mathrm{R}_{\mathrm{t}} \quad=$ Return saham pada periode ke- $\mathrm{t}$

$\mathrm{P}_{\mathrm{t}} \quad=$ Harga saham periode pengamatan

$\mathrm{P}_{\mathrm{t}-1} \quad=$ Harga saham periode sebelum pengamatan

\section{B. Kinerja Keuangan}

Pengertian kinerja berdasarkan Kamus Besar Bahasa Indonesia (2001). Kinerja diartikan sebagai "sesuatu yang dicapai, prestasi yang diperlihatkan, kemampuan kerja (tentang peralatan). Berdasarkan pengertian tersebut kinerja keuangan didefinisikan sebagai prestasi manajemen, dalam hal ini manajemen keuangan dalam mencapai tujuan perusahaan yaitu menghasilkan keuntungan dan meningkatkan nilai perusahaan.

Menurut Ikatan Akuntan Indonesia 1996 dalam Febriyani dan Zulfadin (2003:54), kinerja perusahaan dapat diukur dengan menganalisa dan mengevaluasi laporan keuangan. Informasi posisi keuangan dan kinerja keuangan di masa lalu seringkali digunakan sebagai dasar untuk memprediksi posisi keuangan dan kinerja di masa depan dan hal-hal lain yang langsung menarik perhatian pemakai seperti pembayaran dividen, upah, pergerakan harga sekuritas dan kemampuan perusahaan untuk memenuhi komitmennya ketika jatuh tempo.

Penilaian kinerja perusahaan penting dilakukan baik oleh manajemen, pemegang saham, pemerintah dan pihak lain yang berkepentingan dan terkait dengan distribusi kesejahteraan di antara mereka. Helfert dalam Lidiadni (2003:36) mengemukakan bahwa dalam menilai kinerja perusahaan yang paling berkepentingan adalah pemilik perusahaan dalam hal ini investor, manajer, kreditor, pemerintah dan masyarakat umum. Mereka akan menilai perusahaan dengan ukuran keuangan tertentu sesuai dengan tujuannya. Ketentuan tingkat kesehatan perusahaan dimaksudkan agar dapat digunakan sebagai tolok ukur bagi pihak-pihak yang berkepentingan tersebut. Analisis kinerja keuangan dalam penelitian ini bertujuan untuk menilai implementasi strategi perusahaan dalam hal merger dan akuisisi. Rasio keuangan yang dimaksud dan yang digunakan dalam penelitian ini adalah Return on assets (ROA).

\section{Return on asset}

Return on assets (ROA) merupakan rasio keuangan perusahaan yang berhubungan dengan profitabilitas yang digunakan untuk mengukur kemampuan perusahaan menghasilkan keuntungan atau laba (profitabilitas) pada tingkat pendapatan, asset dan modal saham tertentu (Hanafi dan Halim, 2003:27). Semakin besar ROA perusahaan, semakin besar pula posisi perusahaan tersebut dan semakin baik pula posisi perusahaan tersebut dari segi penggunaan aset. (Dendawijaya, 
2000:120). Secara matematis ROA dapat dirumuskan sebagai berikut (Hanafi dan Halim, 2003) :

Returnon Assets $=\frac{\text { Net profit }}{\text { Total asset }}$

\section{Merger}

Merger merupakan salah satu strategi yang diambil perusahaan untuk mengembangkan dan menumbuhkan perusahaan. Merger berasal dari kata "mergere" (Latin) yang artinya (1) bergabung bersama, menyatu, berkombinasi (2) menyebabkan hilangnya identitas karena terserap atau tertelan sesuatu. Merger didefinisikan sebagai penggabungan dua atau perusahaan yang kemudian hanya ada satu perusahaan yang tetap hidup sebagai badan hukum, sementara yang lainnya menghentikan aktivitasnya atau bubar.

Menurut Moin (2003:5), merger adalah penggabungan dua atau lebih perusahaan yang kemudian hanya ada satu perusahaan yang tetap hidup sebagai badan hukum, sementara yang lainnya menghentikan aktivitasnya atau bubar. Peraturan Pemerintah RI No. 27 Tahun 1998 tentang Penggabungan, Peleburan, dan Pengambilalihan Perseroan Terbatas menyebut merger sebagai penggabungan, akuisisi sebagai pengambilalihan, dan konsolidasi sebagai peleburan (Moin, 2003:5). Definisi merger menurut peraturan pemerintah tersebut adalah perbuatan hukum yang dilakukan oleh satu perseroan atau lebih untuk menggabungkan diri dengan perseroan lain yang telah ada, dan selanjutnya perseroan yang menggabungkan diri menjadi bubar.

Coyle (2003:27) menjelaskan bahwa suatu penggabungan usaha disebut merger jika:

a Tidak ada salah satu perusahaan yang bergabung dapat disebut sebagai perusahaan pengambil alih atau perusahaan yang diambil alih.

b Kedua perusahaan berpartisipasi dalam membentuk struktur manajemen perusahaan hasil penggabungan tersebut.

c Kedua perusahaan yang bergabung pada umumnya memiliki ukuran yanghampir sama, yang artinya tidak ada dominasi aset antara satu perusahaan atas perusahaan yang lain.

d Hampir semua atau sebagian besar melibatkan "share swap", di mana tidak terjadi pembayaran tunai, melainkan yang terjadi adalah penerbitan saham baru yang ditukar dengan kepemilikan saham dalam perusahaan yang lain. 


\section{METODE PENELITIAN}

\section{A. Lokasi Penelitian}

Penelitian ini dilaksanakan pada perusahaan-perusahaan yang terdaftar di Bursa Efek Indonesia periode tahun 2000-2006.

\section{B. Populasi dan Sampel}

Populasi dalam penelitian ini adalah seluruh perusahaan publik yang terdaftar di Bursa Efek Indonesia (BEI) dengan rentang waktu antara tahun 2000- 2006 yaitu sebanyak 334. Sampel perusahaan dipilih secara purvosive sampling, dimana penentuan sampel dilakukan berdasarkan kriteria tertentu sesuai dengan yang dikehendaki peneliti (Kuncoro, 2003:59). Adapun kriteria-kriteria sampel penelitian ini adalah :

a. Perusahaan melakukan merger dan menerbitkan laporan keuangan secara lengkap serta harga saham tersedia dalam periode pengamatan 2000-2006.

b. Tanggal pelaksanaan merger diketahui serta kepemilikan lebih dari $50 \%$.

Berdasarkan populasi penelitian yang ada di Bursa Efek Indonesia (BEI) terdapat sebanyak 74 perusahaan yang melaksanakan merger dan akhirnya diperoleh 34 perusahaan sebagai sampel dalam penelitian ini yang sesuai dengan kriteriakriteria yang ditentukan di atas, sebagaimana yang tampak pada tabel 4.1. dibawah ini.

\section{Metode Pengumpulan Data}

Data yang dipergunakan pada penelitian ini adalah data sekunder. Data sekunder adalah data yang telah dikumpulkan oleh pihak lain dan dipublikasikan kepada masyarakat pengguna (Kuncoro, 2001:61). Data-data tersebut adalah berupa berita-berita merger, laporan keuangan dan harga saham perusahaan-perusahaan sampel yang diperoleh dari Indonesian Capital Market Directory (ICMD) dan website Bursa Efek Indonesia serta didownload dari internet.

\section{Metode Analisis Data}

\section{Pengujian Asumsi Klasik}

Uji normalitas data

Menurut Ghozali (2005:89) Uji normalitas bertujuan untuk menguji apakah dalam model regresi atau variabel pengganggu atau residual berdistribusi normal. Jika data yang diperoleh itu terdistribusi normal dan variansinya sama, maka pengujian hipotesis dilakukan dengan alat statistik parametrik. Jika data yang diperoleh itu tidak terdistribusi normal dan/atau variansinya tidak sama, maka pengujian hipotesis dilakukan dengan alat statistik nonparametrik.

Pada penelitian ini untuk mengetahui apakah variabel dependen, independen atau keduanya berdistribusi normal, mendekati normal atau tidak dapat dilihat dengan menggunakan grafik normal p_plot. Penelitian ini akan melakukan uji normalitas data dengan menggunakan grafik normal p_plot dimana data dikatakan normal bila 
gambar distribusi dengan titik-titik data yang menyebar disekitar garis diagonal dan penyebaran titik-titik data searah mengikuti garis diagonal.

Selain menggunakan grafik p_plot, pengujian normalitas data dilakukan dengan uji Kolmogorov-Smirnov (uji K-S). Jika tingkat signifikansinya lebih besar dari 0.05 , maka data itu terdistibusi normal.

Uji multikolinearitas

Menurut Ghozali (2005:90) Uji multikolinieritas bertujuan untuk menguji apakah model regresi ditemukan adanya korelasi antar variabel bebas (independen). Model regresi yang baik seharusnya tidak terjadi korelasi antar variabel independen. Jika antar variabel independen ada korelasi yang cukup tinggi (umumnya di atas 0.90), maka hal ini mengindikasikan adanya multikolinearitas.

Kemiripan antarvariabel independen dalam suatu model akan menyebabkan terjadinya korelasi yang sangat kuat antara suatu model independen dengan variabel independen yang lain. Pada penelitian ini untuk mendeteksi terhadap multikolineritas dengan melihat Variance Inflation Factor (VIF) pada model regresi. Menurut Nugroho (2005) "Deteksi multikolineritas pada suatu model dapat dilihat bila nilai Variance Inflation Factor (VIF) tidak lebih dari 10 dan nilai Tolerance tidak kurang dari 0,1, maka model dapat dikatakan terbebas dari multikolineritas VIF = $1 /$ Telerance, dan bila VIF $=10$ maka Tolerance $=1 / 10=0,1$. Semakin tinggi VIF maka semakin rendah Tolerance".

Uji heterokedastisitas

Menurut Ghozali (2005:91) Uji Heterokedastisitas bertujuan untuk menguji apakah dalam sebuah model regresi, terjadi ketidaksamaan varians dari residual satu pengamatan ke pengamatan yang lain. Jika varians dari residual dari suatu pengamatan ke pengamatan lainnya tetap, maka disebut Homoskedastisitas. Dan jika varians berbeda, maka disebut heteroskedastisitas. Model regresi yang baik adalah yang homoskedastisitas atau tidak terjadi heteroskedastisitas. Deteksi ada tidaknya dapat dilakukan dengan melihat ada tidaknya pola tertentu pada grafik scatterplot antara SRESID dan ZPRED dimana sumbu Y adalah Y yang telah diprediksi, dan sumbu $\mathrm{X}$ adalah residual ( $\mathrm{Y}$ prediksi dan $\mathrm{Y}$ sesungguhnya) yang telah distudentized). Jika ada pola tertentu, seperti titik-titik yang membentuk pola tertentu (bergelombang, melebir kemudian menyempit), maka mengindikasikan telah terjadi heterokedastisitas. Jika tidak ada pola yang jelas serta titik-titik menyebar di atas dan dibawah angka 0 pada sumbu $\mathrm{Y}$, maka tidak terjadi heterokedastisitas.

Uji autokorelasi

Menurut Ghozali (2005:92) uji autokorelasi bertujuan untuk menguji apakah dalam model regresi linear ada korelasi antara kesalahan pengganggu pada periode $t$ dengan kesalahan pengganggu pada periode t-1 (sebelumnya). Pada penelitian ini, uji autokorelasi dilakukan dengan Uji Durbin Watson, karena uji ini yang umum digunakan. Uji ini hanya digunakan untuk autokorelasi tingkat pertama (first order autokorelasi) dan mensyaratkan adanya intercept (konstanta) dalam model regresi. Pengambilan keputusan ada tidaknya autokorelasi adalah sebagai berikut: 
a. Bila nilai Durbin-Watson (DW) terletak antara batas atas atau Upper Bound (DU) dan 4 - DU, maka koefisien autokorelasi sama dengan nol, berarti tidak ada autokorelasi.

b. Bila nilai DW lebih rendah dari pada batas bawah atau Lower Bound (DL), maka koefisien autokorelasi lebih besar daripada nol, berarti ada autokorelasi positip.

c. Bila nilai DW lebih besar dari pada (4-DL), maka koefisien autokorelasi lebih kecil dari pada nol, berarti ada autokorelasi negatip.

d. Bila nilai DW terletak diantara batas atas (DU) dan batas bawah (DL) atau DW terletak antara (4-DU) dan (4-DL), maka hasilnya tidak dapat disimpulkan.

\section{E. Pengujian Hipotesis}

Berdasarkan model jalur, diajukan hubungan bahwa merger mempunyai hubungan langsung dengan return saham (p1). Namun demikian merger juga mempunyai hubungan tidak langsung ke return saham yaitu dari merger ke kinerja keuangan (p2) baru kemudian ke return saham (p3).

Koefisien jalur adalah standardized koefisien regresi dan dihitung dengan membuat dua persamaan struktural yaitu persamaan regresi yang menunjukkan hubungan yang dihipotesiskan. Dalam penelitian ini persamaan regresi tersebut adalah :

Kinerja keuangan $=\mathrm{b}_{1}$ merger $+\mathrm{e}_{1}$

Return saham $\quad=\mathrm{b}_{1}$ merger $+\mathrm{b}_{2}$ kinerja keuangan $+\mathrm{e}_{2}$

Keterangan :

$\mathrm{b}_{1}, \mathrm{~b}_{2}=$ Koefisien regresi

$\mathrm{e}_{1} \quad=$ Residual atas kinerja keuangan

$\mathrm{e}_{2} \quad=$ Residual atas return saham

Standardized koefisien untuk merger pada persamaan (1) akan memberikan nilai p2. sedangkan koefisien untuk merger dan kinerja keuangan pada persamaan (2) akan memberikan nilai $\mathrm{p} 1$ dan $\mathrm{p} 3$.

\section{HASIL PENELITIAN DAN PEMBAHASAN}

\section{A. Deskripsi Data}

Lokasi penelitian ini adalah Bursa Efek Indonesia yang beralamat di Gedung Bursa Efek Indonesia Lt. 4 Tower 1, Jalan Jenderal Sudirman Kav 52-53 Jakarta Selatan 12190, Telepon (6221)5150515 (hunting). Fax: (6221)5150330. Homepage: www.jsx.co.id, email: webmaster@jsx.co.id. 
Dari data yang diperoleh untuk variabel merger, kinerja keuangan dan return saham dapat dilihat gambaran hasil penelitian statistik deskriptif secara umum berikut ini :

1. Nilai return saham terendah di antara sampel perusahaan adalah sebesar -51 yaitu dihasilkan oleh PT Multipolar Corporation yang mengakuisisi PT Matahari Putra Prima. Return saham tertinggi adalah sebesar 100 yang dihasilkan oleh PT Bumi Resources yang mengakuisisi PT Kaltim Prima Coal.

2. Nilai akuisisi terendah di antara sampel perusahaan adalah $51 \%$ yaitu merger PT Indosiar Karya Media dengan PT Indosiar Karya Media. Nilai akuisisi tertinggi adalah sebesar 100\% diantaranya merger yang dilakukan oleh PT BAT Indonesia dengan Rothmas of Pall Mall Indonesia.

3. Kinerja keuangan terendah diantara sampel perusahaan setelah melakukan merger adalah sebesar -35 yang dihasilkan oleh PT Ades Water Indonesia dan PT Pamargha Indojatim. Kinerja keuangan tertinggi adalah sebesar 29 yang dihasilkan oleh PT Bank Inter Pacifik dan PT Bank Artha Graha.

4. Merger belum mampu meningkatkan kinerja keuangan perusahaan pengakuisisi. Hal tersebut terlihat dari masih rendahnya kinerja keuangan perusahaan pengakuisisi yang melakukan merger. Selain itu kinerja keuangan perusahaan yang melakukan merger juga masih ada yang negatif diantaranya diperoleh oleh PT Unilever Indonesia, PT Selamat Sempurna, PT Multipolar Corporation, PT Bank Inter Pacific, PT Zebra Nusantara, PT Indorama Synthetics, PT Bank OCBC Overseas, PT Surya Toto Indonesia, PT Bakrie Sumatera Plantation, PT Gudang Garam, PT BAT Indonesia, PT Arthavest, PT Sinar Mas Multi Artha dan PT Smart.

\section{B. Pengujian Hipotesis}

Setelah dilakukan pengujian asumsi klasik dan diperoleh kesimpulan bahwa model sudah dapat digunakan, maka langkah selanjutnya adalah melakukan pengujian hipotesis. Pengujian hipotesis dilakukan dengan menggunakan analisis jalur.

Hasil pengujian hipotesis menunjukkan nilai koefisien standardized beta untuk merger pada persamaan regresi (2) adalah 0.363 dan signifikan karena ( $\mathrm{p}=$ $0.041<0.05)$ yang berarti merger berpengaruh terhadap return saham atau merger mempunyai hubungan langsung terhadap return saham perusahaan pengakuisisi. Nilai koefisien standardized beta untuk kinerja keuangan adalah sebesar -0.082 dan tidak signifikan karena $(\mathrm{p}=0.636>0.05)$.

Nilai standardized beta merger 0.363 merupakan nilai jalur p1 dan nilai standardized beta kinerja keuangan $-0,082$ merupakan nilai jalur p3. Besarnya nilai e1 $($ residual kinerja keuangan $)=(1-0,032)^{2}=0,998$ dan besarnya nilai e2 (residual kinerja keuangan $)=(1-0,128)^{2}=0,984$.

Berdasarkan analisis di atas, maka besarnya pengaruh langsung merger terhadap return saham perusahaan pengakuisisi adalah 0.363 sedangkan besarnya pengaruh tidak langsung dihitung dengan mengalikan koefisien tidak langsungnya yaitu $(0.179) \times(-0.082)=-0,097$, sehingga total pengaruh merger terhadap return saham adalah $0.363+(0.179) \times(-0.082)=0.262$. Oleh karena nilai $\left(\mathrm{P}_{2} \times \mathrm{P}_{3}<\mathrm{P}_{1}\right)$ maka 
kinerja keuangan tidak berfungsi sebagai variabel intervening. Hasil analisis jalur dapat digambarkan sebagai berikut :

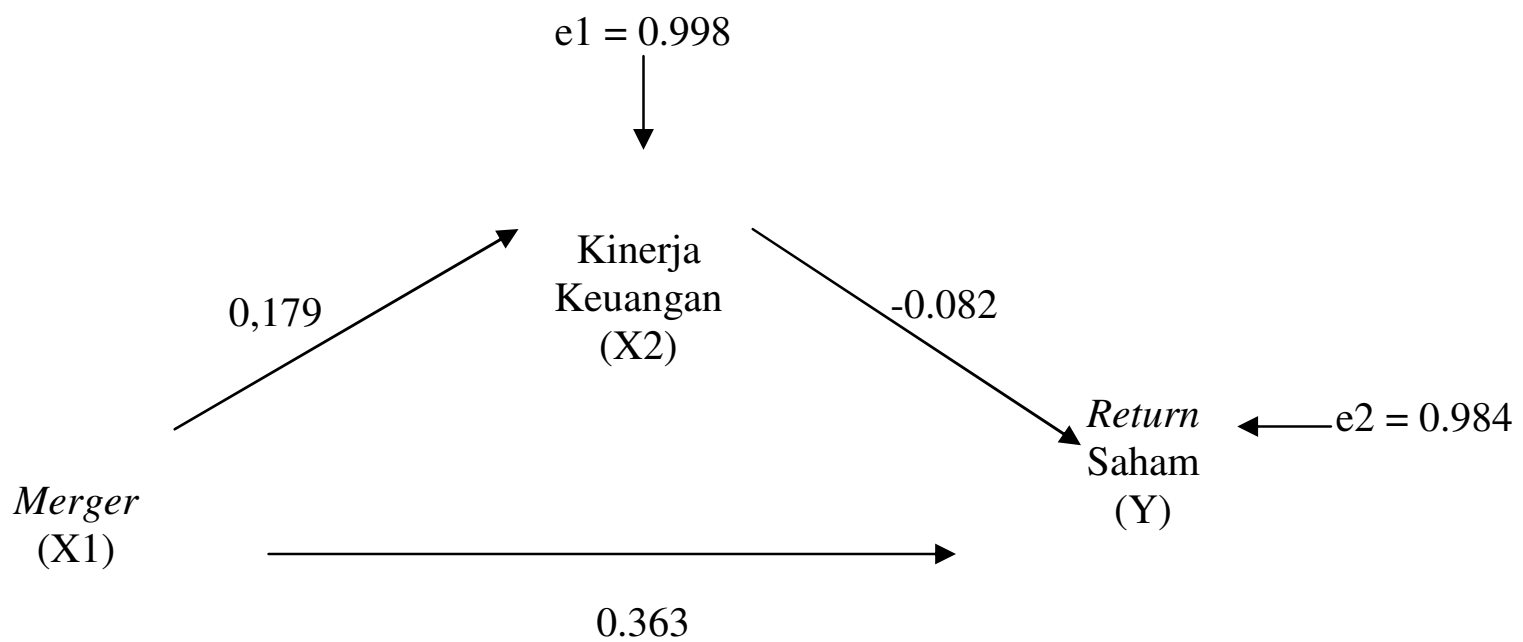

\section{Gambar 5.3. Hasil Pengaruh Merger Terhadap Return Saham Dengan Kinerja Keuangan Sebagai Variabel Intervening}

Hasil analisis jalur di atas menunjukkan bahwa merger berpengaruh positif dan signifikan terhadap return saham atau merger berpengaruh langsung terhadap return saham perusahaan pengakuisisi. Berdasarkan hal tersebut, maka hipotesis penelitian yang menyatakan bahwa merger berpengaruh terhadap return saham mendapat dukungan empiris atau dapat disimpulkan bahwa hipotesis diterima.

Hasil analisis jalur juga menunjukkan bahwa merger tidak berpengaruh terhadap return saham perusahaan pengakuisisi melalui kinerja keuangan sebagai variabel intervening atau secara tidak langsung merger tidak berpengaruh terhadap return saham. Berdasarkan hal tersebut, maka hipotesis penelitian yang menyatakan bahwa merger berpengaruh terhadap return saham perusahaan pengakuisi melalui kinerja keuangan tidak mendapat dukungan empiris atau dapat disimpulkan hipotesis ditolak.

\section{Pembahasan Hasil Penelitian}

Hasil analisis jalur menunjukkan bahwa merger berpengaruh terhadap return saham perusahaan pengakuisisi. Hasil penelitian ini tidak mendukung penelitianpenelitian sebelumnya yang dilakukan oleh Wibowo dan Pakereng (2001) yang meneliti return saham perusahaan akuisitor dan non akuisitor. Hasilnya menunjukkan bahwa baik akuisitor dan non akuisitor sama-sama memperoleh return saham yang negatif di seputar merger. Penelitian lainnya dilakukan Sutrisno dan Sumarsih (2004) yang meneliti return saham perusahaan yang melakukan merger dalam jangka 
panjang yaitu dengan jangka waktu pengamatan satu tahun sebelum dan dua tahun sesudah merger, menunjukkan hasilnya bahwa merger memberi pengaruh pada return saham yang bisa bernilai positif dan negatif walaupun tidak signifikan secara statistik.

Selain itu hasil penelitian ini juga menunjukkan adanya ketidakkonsistenan dengan penelitian-penelitian sebelumnya, namun masih sejalan dengan teori-teori yang ada. Teori menyatakan bahwa merger akan menyebabkan ukuran perusahaan dengan sendirinya bertambah besar karena aset, kewajiban, dan ekuitas perusahaan digabung bersama. Ukuran perusahaan yang bertambah besar dan dengan sinergi yang dihasilkan dari gabungan aktivitas-aktivitas yang simultan akan meningkatkan laba dan return saham.

Hasil penelitian yang menunjukkan bahwa merger berpengaruh terhadap return saham perusahaan pengakuisisi menggambarkan bahwa Pemerintah Indonesia sudah semakin meningkatkan pengawasan terhadap perusahaan-perusahaan yang melakukan merger.

Hasil analisis jalur juga menunjukkan bahwa merger tidak berpengaruh terhadap return saham perusahaan pengakuisisi melalui kinerja keuangan yang diukur dengan ROA sebagai variabel intervening (pengaruh tidak langsung). Hal ini terlihat dari nilai koefisien standardized beta merger pada persamaan (1) sebesar 0,179 dan tidak signifikan pada 0,310 ( $>00,05)$, yang berarti merger tidak mempengaruhi kinerja keuangan. Nilai koefisien standardized beta 0,179 merupakan nilai path atau jalur p2. Pada hasil persamaan regresi (2) nilai koefisien standardized beta untuk kinerja keuangan $-0,082$ tidak signifikan pada 0.636 . nilai standardized beta kinerja keuangan -0,082 merupakan nilai jalur p3. Hal ini menunjukkan bahwa kinerja keuangan yang diukur dengan ROA tidak berlaku sebagai variabel intervening.

Hasil penelitian ini tidak dapat dibandingkan dengan penelitian-penelitian sebelumnya karena variabel-variabel yang berbeda serta alat analisis yang berbeda, dimana dalam penelitian ini menggunakan kinerja keuangan sebagai variabel intervening dan pengujian hipotesis menggunakan analisis jalur sedangkan penelitianpenelitian sebelumnya hanya menggunakan variabel independen dan uji beda sebagai alat analisisnya.

Hasil penelitian ini tidak sejalan dengan teori, dimana seharusnya segera setelah merger, ukuran perusahaan dengan sendirinya bertambah besar karena aset, kewajiban dan ekuitas perusahaan digabung bersama. Jika "size" bertambah besar ditambah dengan sinergi yang dihasilkan dari gabungan aktivitas-aktivitas yang simultan, maka laba perusahaan juga semakin meningkat. Oleh karena itu kinerja keuangan perusahaan dalam hal ini adalah ROA pasca merger diprediksi akan semakin baik dibandingkan dengan sebelum merger. Dengan adanya kinerja keuangan perusahaan berupa ROA yang tinggi, maka ketertarikan investor juga akan meningkat, sehingga kondisi tersebut akan berdampak pada peningkatan harga dan return saham.

Terdapat beberapa kemungkinan untuk menjelaskan hasil tersebut. Pertama, hasil ini membuktikan bahwa kinerja keuangan, khususnya ROA tidak memiliki muatan informasi yang digunakan untuk menentukan return saham. Pasar Modal Indonesia memiliki bentuk efisiensi yang lemah (weak form efficiency), yang berarti 
keadaan pada saat harga-harga mencerminkan semua informasi yang ada pada catatan harga di masa lalu. Dalam keadaan seperti ini seorang pemodal tidak dapat memperoleh tingkat keuntungan yang lebih tinggi dari keadaan normal dengan menggunakan trading rules yang berdasarkan atas informasi harga di waktu lalu, atau perubahan harga saham di masa lalu tidak bisa dipergunakan untuk memperkirakan harga saham di masa mendatang.

Pasar Modal Indonesia yang lemah menyebabkan kurangnya investor untuk melakukan permintaan terhadap saham. ROA tidak dapat dijadikan sebagai acuan dalam melakukan analisis pasar, karena ROA dihasilkan dari informasi keuangan historis. ROA yang tidak memiliki muatan informasi untuk memprediksi saham menyebabkan investor tidak berminat untuk membeli saham, sehingga mengurangi permintaan terhadap suatu saham. Berkurangnya permintaan atas saham-saham di Bursa Efek Jakarta konsekuensinya adalah turunnya harga saham, sehingga tidak dapat meningkatkan return saham.

Selain itu, karakteristik data dalam Pasar Modal Indonesia yang digunakan dalam penelitian ini mungkin kualitasnya lebih rendah, artinya datanya sulit diprediksi dibandingkan dengan di negara-negara maju seperti Amerika. Kondisi semacam ini menurut hemat peneliti diperkirakan karena adanya informasi yang tidak simetris (asymetry information), dimana manajer sebagai pengelola perusahaan lebih banyak mengetahui informasi internal dan prospek perusahaan di masa yang akan datang dibandingkan pemilik (pemegang saham) dan pihak-pihak lain. Oleh karena itu sebagai pengelola, manajer berkewajiban memberikan sinyal mengenai kondisi perusahaan kepada pemilik. Sinyal yang diberikan dapat dilakukan melalui pengungkapan informasi akuntansi seperti laporan keuangan.

\section{BAB VI \\ KESIMPULAN DAN SARAN}

\subsection{Kesimpulan}

Berdasarkan analisis dan pembahasan yang telah dikemukakan sebelumnya maka dapat ditarik kesimpulan sebagai berikut :

A. Hasil hipotesis pertama menunjukkan bahwa merger berpengaruh positif dan signifikan terhadap return saham perusahaan pengakuisisi yang berarti merger berpengaruh langsung terhadap return saham perusahaan pengakuisisi. Hasil penelitian ini tidak sejalan dengan penelitian terdahulu yang dilakukan oleh Wibowo dan Pakereng (2001), namun masih sejalan dengan teori.

B. Hasil hipotesis kedua menunjukkan bahwa merger tidak berpengaruh terhadap return saham melalui kinerja keuangan yang diukur dengan ROA sebagai variabel intervening. Hasil penelitian ini tidak dapat diperbandingkan dengan penelitianpenelitian sebelumnya, karena tidak adanya peneliti yang melakukan penelitian yang sama dengan penelitian ini. Hasil penelitian ini juga menunjukkan adanya ketidaksesuaian dengan teori, dimana seharusnya segera setelah merger, ukuran perusahaan dengan sendirinya bertambah besar karena aset, kewajiban dan ekuitas perusahaan digabung bersama. jika "size" bertambah besar ditambah 
sinergi yang dihasilkan dari gabungan aktivitas-aktivitas yang simultan, maka laba perusahaan juga semakin meningkat. oleh karena itu kinerja keuangan perusahaan dalam hal ini adalah ROA pasca merger diprediksi akan semakin baik dibandingkan dengan sebelum merger. Dengan adanya kinerja keuangan perusahaan berupa ROA yang tinggi, maka ketertarikan investor juga akan meningkat, sehingga kondisi tersebut akan berdampak pada peningkatan harga dan return saham.

\subsection{Keterbatasan Penelitian}

Penelitian ini memiliki keterbatasan antara lain adalah:

1. Hasil penelitian ini hanya dapat dijadikan analisis pada obyek penelitian yang terbatas pada perusahaan pengakuisisi dan tidak mengikutsertakan perusahaan yang diakuisisi, sehingga penelitian ini tidak dapat melihat pengaruh merger terhadap return saham dengan kinerja keuangan yang diukur dengan ROA sebagai variabel intervening pada perusahaan yang diakuisisi.

2. Variabel yang digunakan untuk mengukur pengaruhnya terhadap return saham pada penelitian ini, hanya sebatas merger sebagai variabel dependen dan kinerja keuangan yang diukur dengan ROA sebagai variabel intervening, sehingga masih banyak kemungkinan faktor lain yang dapat mempengaruhi return saham.

3. Jumlah periode pengamatan penelitian ini adalah enam tahun (periode 20002006). Ini menyebabkan perusahaan-perusahaan yang merger pada periode 20072009 tidak dijadikan sampel pada penelitian ini. Sementara berdasarkan informasi-informasi yang ada bahwa pada periode 2006-2009 ada perusahaanperusahaan yang melakukan merger.

\subsection{Saran}

Berdasarkan kesimpulan dan keterbatasan dalam penelitian ini, maka dapat dikemukakan beberapa saran sebagai berikut :

1. Memperluas obyek penelitian yang tidak terbatas pada perusahaan pengakuisisi saja dengan menambah perusahaan yang diakuisisi sebagai sampel, sehingga memungkinkan adanya perbandingan pengaruh merger terhadap return saham dengan kinerja keuangan sebagai variabel intervening antara perusahaan pengakuisisi dan perusahaan yang diakuisisi.

2. Penelitian ini perlu dikembangkan lebih jauh lagi, untuk mendapatkan hasil empirik yang lebih kuat yaitu dengan menambah variabel-variabel lain seperti pengumuman dividen, stock split dan current ratio.

3. Bagi Peneliti selanjutnya disarankan perlu memperpanjang periode pengamatan, sehingga jumlah sampel perusahaan lebih besar dan lebih beragam. Perpanjangan periode penelitian dan penambahan jumlah sampel mungkin akan memberikan hasil yang lebih baik. 


\section{DAFTAR PUSTAKA}

Adams, C. and A. Neely. (2000). "The Performance Prism to Boost M\&A Success". Measuring Business Excellence. Vol 4 No.3 pp. 19-23.

Alwi, Z. Iskandar. (2003). Pasar Modal Teori dan Aplikasi. Edisi Pertama. Jakarta: Penerbit Yayasan Pancur Siwah.

Ang, Robert. (1997). Buku Pintar: Pasar Modal Indonesia: Media Soft Indonesia.

Appelbaum, A.H., J. Gandel, B.T. Shapiro, P. Bellsle \& E. Hoeven. (2000). "Anatomy of a Merger. Behavior of Organizational Factors and Processes throughout the pre- during-post-Merger Part 1 \& 2". Management Decision. Vol 38 No 10 pp. 649 - $661 \&$ 674-684

Asna and Nugraha (2006). “Analisis Pengaruh Rasio Keuangan Terhadap Return Saham Perbankan yang Terdaftar di Bursa Efek Jakarta" Ekonomi Modernisasi, Vol. 2 No. 3 (Oktober 2006).

Brigham, Eugene F dan Joel F Houston (terj.) (2001). Manajemen Keuangan. Jilid 2. Edisi 8. Jakarta: Erlangga.

Brigham, Eugene F., Gapenski, Louis C., dan Ehrnart, Michel C. (1999). Financial Management Theory and Practice. Orlando: The Dryden Press.

Corrado, Charles J. and Jordan, Bradford D. (2000). Fundamentals of Investment Analisis Fourth Edition. Singapore: Mc Graw-Hill.

Covin, T,J., T.A. Kolenko, K.W. Sightler and R.K. Tudor. (1997). "Leadership Style and Post-Merger Satisfaction". Journal of Management Development. Vol 16 No.1 pp. 22-33

Coyle Brian. (2000). Mergers and Acquisition. New York: Amacom.

Dendawijaya, L. (2001). Manajemen Perbankan. Jakarta: Ghalia Indonesia.

Febryani, Anita dan Zulfadin, Rahadian (2003). "Analisis Kinerja Bank Devisa dan Bank Non Devisa di Indonesia”. Kajian Ekonomi dan Keuangan, Volume 7 No. 4. Jakarta.

Halim, Abdul (2003). Analisis Investasi. Jakarta : Salemba Empat. 
Hanafi, Mamduh dan Halim, Abdul. (2003). Analisis Laporan Keuangan. Yogyakarta: UPP AMP YKPN.

Hitt, Michael A., Jeffey S. Harrison dan R. Diane Ireland (terj.) (2002). Merger dan Akuisisi: Penduan Meraih Laba Bagi Para Pemegang Saham. Jilid 1, Edisi 1, Jakarta: Raja Grafindo Persada.

Horne, James C. V. and Wachoviz Jr, John M. (1998). Fundamental of Financial Management 8th ed, New Jersey: Prentice Hall International

Hoyle, Schaefter and Doupnik (2004). Advance Accounting. Seventh Edition, International Edition: Mc Graw Hill.

Husnan, Suad (1998). Manajemen Keuangan, Teori dan Penerapan (Keputusan Jangka Pendek), Yogyakarta: BPFE.

1994 . Dasar-Dasar Teori Portofolio dan Analisis Sekuritas. Edisi Kedua. Yogyakarta: UPP AMP YKPN.

Jogiyanto (2003). Teori Portofolio dan Analisis Investasi (Edisi Ketiga), Yogyakarta: BPFE.

Kotter, J.P. and J.L. Heskett (1992). Corporate Culture And Performance. New York: The Free Press

Kuncoro, Mudrajat (2001). Metode Riset untuk Bisnis dan Ekonomi, Jakarta: Erlangga.

Moin, Abdul. (2003). Merger, Akuisisi dan Divestasi. Jilid 1. Yogyakarta: Ekonisia.

Muhammad, Swarsono. (2004). Manajemen Strategik: Konsep dan Kasus. Jilid 1. Edisi Ketiga. Yogyakrta: UPP AMP YKPN.

Mulyadi. (2001). Akuntansi Manajemen: Konsep, Manfaat dan Rekayasa. Edisi 3. Yogyakarta: Bagian Penerbitan Universitas Gajah Mada.

Munawir, S. (2002). Analisa Laporan Keuangan. Yogyakarta: Liberty.

Neil, M. Kay. (1997). Pattern in Corporate Evolution, New York: Oxford University Press.

Payamta, dan Doddy Setiawan (2004). "Analisis Pengaruh Merger dan Akuisis Terhadap Kinerja Perusahaan Publik di Indonesia." Riset Akuntansi Indonesia, Vol. 7 No. 3 (September). 265-282. 
Pringle, J.J. and Harris, R.S (1987). Essential of Managerial Finance. $2^{\text {nd }}$. London: Illinois

Riyanto, Bambang. (2001). Dasar-dasar pembelanjaan Perusahaan Edisi 4. Yogyakarta: BPFE.

Robbins, S.T. (2000). Organizational Behaviour. New Jersey: Prentice Hall Inc.

Ross, S.A, Westerfield, R.W \& Jaffe (2002). Corporate Finance, ( $6^{\text {th }}$ Edition), USA: Mc Graw-Hill, Inc.

Rubrik Eurika (2002). Investasi Saham di Pasar Modal. Jakarta: Http:/www.redaksi@ sinarharapan.co.id.

Schein, E.H. (1997). Organizational Culture and Leadership. Fransisco: Jossey-Bass

Sudarsanam, P.S (terj.) (1999). The Essence of Mergers and Acquisitions. Jilid 1. Edisi 1. Yogyakarta: ANDI.

Sunariyah. (2003). Pengantar Pengetahuan Pasar Modal. Edisi Ketiga. Yogyakarta: Penerbit UPP AMP YKPN.

Sutrisno, dan Sumarsih (2004). "Dampak Jangka Panjang Merger dan Akuisisi Terhadap Pemegang Saham di BEJ Perbandingan Akuisisi Internal dan Eksternal" Akuntansi \& Auditing Indonesia, Vol. 8 No. 2 (Desember). 189210.

Tandelin, Eduardus (2001). Analisis Investasi dan Manajemen Portofolio. Edisi Pertama, Yogyakarta: Penerbit BPFE.

Tim Penyusun Kamus Pusat Pembinaan dan Pengembangan Bahasa. (1994). Kamus Besar Bahasa Indonesia. Jakarta: Balai Pustaka

Ulupui (2006). "Pengaruh Rasio Likuiditas, Leverage, Aktivitas dan Profitabilitas Terhadap Return Saham (Studi Pada Perusahaan Makanan dan Minuman Dengan Kategori Industri Barang Konsumsi di Bursa Efek Jakarta" Kinerja, Vol. 11 No. 2 (2007). 98-112.

Wahana. (2006). Belajar Praktis Menguasai SPSS 13 Untuk Statistik. Jilid 1. Edisi 1. Jakarta: Salemba Infotek

Wahyudi, Sugeng. (2003). "Pengukuran Return Saham" Jurnal Ekonomi. Suara Merdeka. 
Wibowo, Amin dan Yulita Milla Pakereng (2001). "Pengaruh Pengumuman Merger dan Akuisisi terhadap Return Saham Perusahaan Akuisitor dan Non Akuisitor dalam Sektor Industri Yang Sama di Bursa Efek Jakarta" Ekonomi \& Bisnis Indonesia, Vol. 16 No. 4 (Oktober). 373-387.

Widjanarko, Hendro (2006). "Merger, Akuisisi dan Kinerja Perusahaan Studi Atas Perusahaan Manufaktur Tahun 1998-2002.” Utilitas, Vol. 14 No.1 (Januari). $39-49$.

Whalen, P.T. (2000). Study to Explore How Communication Drive Merger Success. Working Paper. 